\title{
Patents, ownership and sovereignty
}

Sir - The debate about the draft European Commission directive on the legal protection of biotechnological inventions, soon to be submitted to the European Parliament (Nature 390, 429; 1997), appears to have paid little regard to the views of laboratory bench scientists.

Results of a survey of users of the MRCfunded Human Genome Mapping Project (HGMP) Resource Centre (P. Glasner et al. Genome News Winter 26-32; 1997) provide a significant insight into the attitudes of researchers working on the HGMP on the wider issues surrounding genome research such as patenting and commercialization (see table). A stratified sample of 1,000 users generated a $52.5 \%$ response rate, with nearly $90 \%$ located in the United Kingdom. Two-thirds of our respondents were situated in either a hospital or higher education environment, and a similar proportion were research scientists; very few were in the private sector. More than $80 \%$ were actively involved in projects relevant to human genome research.

The greatest unanimity of view was expressed in a concern about the patenting of sequenced material. One respondent put the position starkly: "The patenting of any discovered genetic sequences is immoral and unethical. It should remain or be illegal."
More than $85 \%$ of respondents either wholly or partially agreed that patenting could impede the development of diagnostics and therapeutics. More moderate responses, however, acknowledged that genome research is inextricably linked to financial interests, and that the issues arising from this need to be addressed.

A question on whether the current attempts to commercialize the results of the HGMP are premature did not arouse the same depth of feeling. Nearly one-third of respondents felt strongly that they are, another third mildly agreed and one respondent reiterated the need by all for access to knowledge in this area. This apparent paradox suggests the need for further attitudinal research.

\section{Peter Glasner}

\section{Harry Rothman}

Science \& Technology Policy Unit, University of the West of England, Bristol BS16 1QY, UK

e-mail:h-rothman@wpg.uwe.ac.uk

Sir - You reported a call for a moratorium on patents on seeds held by the Consultative Group on International Agricultural Research (CGIAR) (Nature $391,728 ; 1998)$. This is 'NGO-speak'. Samples are not being 'patented' but placed

\begin{tabular}{|c|c|c|c|c|c|}
\hline & $\begin{array}{l}\text { Disagree } \\
\text { strongly }\end{array}$ & $\begin{array}{l}\text { Disagree } \\
\text { mildly }\end{array}$ & Indifferent & $\begin{array}{l}\text { Agree } \\
\text { mildly }\end{array}$ & $\begin{array}{l}\text { Agree } \\
\text { strongly }\end{array}$ \\
\hline $\begin{array}{l}\text { HGMP has drawn funds away } \\
\text { from more worthwhile } \\
\text { biological research, } n=507\end{array}$ & 41.0 & 26.8 & 24.1 & 6.3 & 1.8 \\
\hline $\begin{array}{l}\text { HGMP poses new ethical } \\
\text { issues for society, } n=509\end{array}$ & 9.8 & 13.6 & 18.9 & 34.8 & 23.0 \\
\hline $\begin{array}{l}\text { Patenting of partial and } \\
\text { uncharacterized cDNA } \\
\text { sequences without knowledge } \\
\text { of their biological function will } \\
\text { impede the future development } \\
\text { of diagnostics and } \\
\text { therapeutics, } n=508\end{array}$ & 3.9 & 3.1 & 6.1 & 22.4 & 64.4 \\
\hline $\begin{array}{l}\text { Current attempts to commercialize } \\
\text { the results of the HGMP are } \\
\text { premature, } n=503\end{array}$ & 2.6 & 8.3 & 27.8 & 32.0 & 29.2 \\
\hline $\begin{array}{l}\text { HGMP will advance technology } \\
\text { and techniques more than } \\
\text { biological theory and } \\
\text { science, } n=502\end{array}$ & 11.4 & 24.9 & 26.9 & 28.1 & 8.8 \\
\hline
\end{tabular}

under Plant Variety Rights (PVR) legislation. Although CGIAR claims 'global trustee' status for its collections, this is selfassigned; no country has ever formally allocated trustee status over its varieties to the CGIAR, and the legal status of the

CGIAR collections remains uncertain.

Indeed, most of the varieties in CGIAR genebanks are duplicates of national collections. CGIAR collecting expeditions over the past three decades left original samples in national genebanks. These original samples have clearly always been under national sovereignty, and are certainly now covered by the articles of the Convention on Biodiversity.

At least one CGIAR institute - the International Center for Agricultural Research in the Dry Areas (ICARDA) in Syria - has recognized this. As each CGIAR institute is responsible for the terms of its material transfer agreement restricting the use of collections, ICARDA has sensibly asked those receiving samples to contact the country of origin if the recipient wishes to process samples for PVR. Attempts by any outside body to prevent this would be a clear breach of the biodiversity convention, which encourages such deals to support the use and conservation of biodiversity.

The World Bank, as the parent body of CGIAR, seems to be infringing the sovereignty of the country of origin by ignoring the provisions of the convention, and is even claiming retroactivity for a contractual agreement about CGIAR collections between CGIAR institutes and the Food and Agriculture Organization (FAO); this allows CGIAR monopoly rights over samples, and even over the interests of the country of origin. The confusion stems from the faulty agreement between FAO and CGIAR. This should now be changed to recognize national sovereignty over the collections that CGIAR has 'borrowed' from countries of origin.

David Wood

13 Herons Quay,

Milnthorpe, Cumbria LA7 7HW, UK

e-mail:113077.3244@compuserve.com

\section{Send not to know...}

Sir - Jonathan Slack was perceptive in his book review where he discussed the challenges faced by students of developmental biology (Nature 391, $857-858$; 1998). One problem of terminology causes particular confusion. The example from Lewis Wolpert's book Principles of Development illustrates the point well, which Slack did not address directly.

The example was: "As a result of Toll receptor activation cactus protein is degraded...." This sentence is about the protein Toll, which is a receptor that is activated by binding its ligand, Spaetzle. In other words Toll is the receptor for Spaetzle, just as the insulin receptor is the receptor for insulin. The sentence does not refer to a receptor for which Toll is the ligand. Such confusing use can be found in many textbooks on developmental biology where it causes great difficulty for students new to the subject. Is it too late for clarity on this point?

\section{Robert W. Old}

Developmental Biology Group,

University of Warwick,

Coventry CV4 7AL, UK 